Kernos, suppl. 16 (2006), p. 211-238.

Originalveröffentlichung in: E. Stavrianopoulou (Hrsg.), Ritual and Communication in the Graeco-Roman

World, Liège 2006, S. 211-238

\title{
Rituals between Norms and Emotions: Rituals as Shared Experience and Memory
}

\section{An unforgettable procession and the emotional dimen- sions of rituals}

A grave inscription found in Ithaca preserves no more than a name, and this not even complete. ${ }^{1}$ Several readings have been suggested: Onpodoros, Arpodoros, and Karpodoros. None of them makes any sense. From the facsimile of $G$. KRUUGER we may infer that we are dealing with the name

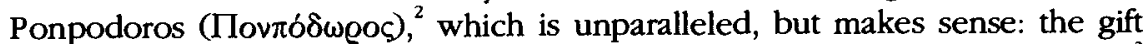
of the pompe. Names composed with -doros are so called theophoric names. They express the belief that a divinity provided assistance for or during the birth of a child. Apollodoros, e.g., 'the gift of Apollo', commemorates either an oracle announcing the birth of a child ${ }^{4}$ or a vow made by the parents. The child Ponpodoros was the gift of a procession, but in what sense? Comedies, novels, and poetry inform us time and again that a religious procession was one of the occasions on which women left the house and were struck by Eros or bad luck. ${ }^{5}$ Ponpodoros may have been born during a procession, or a procession was the occasion on which his mother met the father, or had sexual intercourse with him, or was raped. This procession was hard to forget.

Rituals are emotionally loaded activities. ${ }^{6}$ They often intensify emotions and pre-existing tensions among persons and groups. It occasionally occurred that festivals and other celebrations were disturbed by violent events, e.g., by the attempts to murder a statesman or by attacks against worshipers. Kylon attempted to occupy the Acropolis in Athens during the celebration of the Diasia (before $630 \mathrm{BC}$ ), the Peisistratid Hipparchos was murdered during the procession of the Panathenaia $(514 \mathrm{BC}$ ), an attempt to murder the Karian

IG $\mathrm{IX}^{2} 1.4,1638$.

2 Already suggested by H. vON PROTT, "Neue Inschriften aus Ithaka", MDAI(A) 27 (1902), p. $377, \mathrm{n}^{\circ} 62$ on the basis of this facsimile; cf. my comments in $S E G 51,663$.

3 R. PARKER, "Theophoric Names and the History of Greek Religion", in S. HORNBLOWER, E. MATTHEWS (eds), Greek Personal Names. Their Value as Evidence, Oxford, 2000, p. 53-79.

${ }^{4}$ Cf. R. PARKER, l.c. (n. 3), p. 63, with regard to F.Delphes III.1, 560; a child born in accordance with an oracle of Apollo was given the name Delphis.

${ }^{5}$ Rape of women during festivals: e.g., Menander, Bpitrepontes, 234-237; Ps.-Heracl., epist., VII (ed. ATTRIDGE). Love at first sight during a festival: see infra on Theocritus' Second Idyll.

${ }^{6} \mathrm{~S}$. GÖDDE, "Emotionale Verschiebungen. Zur Bedeutung der eupbemia im griechischen Ritual", in A. KNEPPE, D. METZLER (eds), Die emotionale Dimension antiker Religiositat, Münster, 2003, p. 21-46 (with further bibliography). 
dynast Maussolos occurred during a festival in the sanctuary of Zeus Labraundos near Mylasa (355/4 BC), a group of religious fanatics in Sardeis attacked the worshipers of Artemis Ephesia during a procession (c. 340-320 $\mathrm{BC}$ ), and it is not unlikely that the murders in the sanctuary of Alea in Tegea that are mentioned in an inscription occurred during a festival. ${ }^{7}$ A new inscription from Kollyda in Lydia (AD 197/98) narrates an attack against a sanctuary during the celebration of a festival: people came together and, armed with swords, sticks, and stones, attacked the sacred slaves and smashed the statues of the gods.

Intense emotions were sometimes to be expected (e.g., in funerals) or were deliberate, e.g., in oaths, curses, and confessions. ${ }^{9}$ For the understanding of rituals one needs to consider not only the norms that regulated them, but also the emotions of the participants and the tensions among them that threatened to undermine the rituals.

There also exist, of course, rituals, which are performed in isolation. One deposits alone a defixio in a grave during a night ceremony; one may pray alone; and under certain conditions a funerary ritual may be performed by a single person. And yet, even these rituals that are performed in isolation - and for this reason will not be treated here - usually presuppose at least one other person: the hated opponent who is being cursed, the beloved person on behalf of whom one prays, the deceased relative to whom one brings an offering. Most rituals presuppose the co-existence or the confrontation of human beings who know, like, love, or hate one another.

That rituals contribute to the creation of an identity is often - and aptly stressed; but beyond the identity of the group there exist the emotions of the individuals and the manifold tensions in interpersonal relations. Let us consider for a moment one of the most common rituals: the procession. A representative normative ritual text, a decree of the city Antioch on the

7 Kylon: Thucydides, I, 126, 6; Hipparchos: Thuc., I, 20, 2; Maussolos: I. Mylasa 3; Sardeis: I.Ephesos 2; SEG 36, 1011; Alea: IG V.2, 262 = L. DUBOIS, Recherches sur le dialecte arcadien, Louvain-la-Neuve, 1986, II, p. 94-111; G. THÜR, H. TAEUBER, Prozessrecbtlicbe Inschriften der griechischen Poleis. Arkadien, Vienna, 1994 (SB Akad. Wien, 607), p. $75-98 \mathrm{n}^{\circ}$ 8; A. CHANIOTIS, "Conflicting Authorities: Greek Asylia between Secular and Divine Law in the Classical and Hellenistic Poleis", Kernos 9 (1996), p. 75-77; G. THÜR, "Gerichtliche Kontrolle des Asylanspruchs", in M. DREHER (ed.), Das antike Asyl. Kultiscbe Grundlagen, recbtliche Ausgestaltung und politiscbe Funktion, Cologne, 2003, p. 29-30. For further examples see A. CHANIOTIS, "Gedenktage der Griechen: Ihre Bedeutung für das Geschichtsbewußtsein griechischer Poleis", in J. ASSMANN (ed.), Das Fest und das Heilige. Religiöse Kontrapunkte zur. Alltagswelt, Gütersloh, 1991, p. 136.

${ }^{8}$ P. HERRMANN, H. MAlaY, New Documents from Lydia, Vienna, 2006 (forthcoming), $n^{\circ} 83$.

9 For emotional language in curse inscriptions see H.S. VERSNEL, "Sachliche Sprache und emotionale Sprache in griechischen und römischen Fluch-Texten", in KNEPPE - METZLER (eds), o.c. (n. 6), p. 87-116. For references to emotions (especially honor and shame) in the confession inscriptions see A. CHANIOTIS, "Von Ehre, Schande und kleinen Verbrechen unter Nachbarn: Konfliktbewältigung und Götterjustiz in Gemeinden des antiken Anatolien", in F.R. PFETSCH (ed.), Konflikt, Heidelberg, 2004, (Heidelberger Jabrbücher, 48), p. 245-251, with further bibliography. 
Pyramos (c. $160 \mathrm{BC}$ ), gives the following instructions for the performance of a procession on the day of a commemorative festival: ${ }^{10}$

On the day, on which the altar was founded, a procession as beautiful and glamorous as possible will be held every year, leading from the altar of the council to the sanctuary of Athena. The procession will be headed by the demioungos (the highest official of the city) and the prytaneis (the members of the council). They will offer a sacrifice of a cow with gilded homs to Athena and to Homonoia (the Concord). The priests, all the other magistrates, the winners of the athletic contests, the supervisor of the gymnasium with all the ephebes and the young men, and the supervisor of the boys with all the boys, shall attend the procession. This day will be a holiday; all the citizens shall wear garlands.

This procession will unavoidably be attended by the elected magistrates and their defeated political opponents, by the victorious athletes and the loosers, by the youngsters of the wealthy families, who were accepted into the elite institutions of the ephebeia and the gymnasium, and by the sons of the artisans. The procession, with its clear hierarchical structure, underscores and confirms social distinctions. There is no need to mention that this procession was also attended by the opponents in law-suits, by the debtor and the creditor, the cheated husband and his competitor, the young man in love and the beauty who ignores him. The tensions among these persons remain unmentioned. The text evokes harmony; after all the festival was dedicated to the goddess of concord. But at a closer look we notice that the text evokes harmony precisely because it is aware of the danger of conflict:

... All shall be released from work, the slaves shall be released from chains. The magistrates and the winners of the contests shall gather in the sanctuary of Athena, all the other citizens will gather in groups according to the civic subdivisions (the tribes). The bieromnemon (a sacred official) and the presidents of the tribes will be responsible for order on this day ...

All inhabitants are expected to attend, including the workers and the slaves. Envy caused because of social inequality should not undermine the celebration of concord. The citizens are to gather in small groups, in groups of people who know one another. And the explicit mention of measures for order shows that quarrels were to be expected.

Emotions and tensions - political, social, cultural, or sexual - can influence the performance of rituals. Every reader will affirm this, not on the basis of historical studies, but of personal experience. Who cannot recall a birthday party or a Christmas, Thanksgiving, Easter, Passover or whichever celebration, that tumed into a stage for the explosion of emotions? This paper is concerned with the question of whether cult regulations, particularly of the Hellenistic and Roman Imperial period, took into consideration this universal experience.

${ }^{10}$ LSAM 81. Cf. A. ChANiotis, "Sich selbst feiern? Die städtischen Feste des Hellenismus im Spannungsfeld zwischen Religion und Politik", in P. ZANKER, M. WÖRRLE (eds), Stadtbild und Bürgerbild im Hellenismus, Munich, 1995, p. 156-160. 


\section{The question: Do norms reflect emotions?}

Rituals that were publicly performed are hardly ever described in our sources, even when - in fact, particularly when - they were regularly performed. Our reconstructions resemble jigsaw puzzles, with the notable difference that we do not have all the pieces and that we do not know how the picture that we are supposed to reconstruct looks like. And the problems do not end there. A description of or an allusion to the performance of a ritual on a particular occasion is not always reliable, since it does not necessarily distinguish between the norm and possible deviations. A variety of factors may indeed result in deviations from the norm: particular social conditions or historical contexts, the joy of innovation or budgetary constraints, but also the emotions of the participants and the tensions among them. As a complex act of communication between performers, spectators, and addressees, the living and the dead, mortals and gods, the effect of rituals may differ from performance to performance.

The question hidden behind the vague title of my paper is quite simple: Did the norms that regulated the conduct of rituals take into consideration the emotions, which unavoidably underlie every individual performance of a ritual? Were rituals understood in the Greek world as an intense shared experience? And did the Greeks intend the performance of rituals to be an emotional experience of togetherness? And if this was indeed intended, how did the sacred regulations reflect the anxiety that emotions might disturb the performance of rituals, but also the efforts to restrain uncontrolled emotions and provoke desirable reactions, in particular the feeling of togetherness?

I introduce my discussion of these questions in an unorthodox way, by quoting fiction $(\$ 3$ ). I shall then argue that rituals were remembered as an emotional experience for a long time after their performance and that this shows the strong emotional background of the performance of rituals ( $\$ 4)$. The discussion of a particular detail in the performance of funerary rituals the physical contact between mourners and the deceased - will serve as an example of how the demonstration of emotions communicated the close relationship between two persons, but also the feeling of togetherness with a group $(\$ 5)$. In light of literary sources, inscriptions, and the vocabulary of rituals I shall argue that rituals were often intended to be an experience of togetherness $(\$ 6)$. Finally, I shall conclude that it was for this reason that measures were taken in order to ensure the harmonious interaction among the participants and, ultimately, their undisturbed communication with the addressees of the rituals $(\$ 7)$.

\section{Imagining the emotional context of rituals}

'Use pious words!', exclaimed the bearded man, as be noticed the red solar disk approacbing the ridge of the mountain. The last rays of the all-seeing god fell on the sharpened blade of the bronze knife, which the priest Tryphon was bolding in bis band; the gilded nail-beads on the bandle glistened for a last time, before Tryphon with a quick and skilful movement, betraying long experience, cut through the 
throat of the one-year-old sheep which two youths bad raised above the altar. The blood stained their faces and their clothes, the knife's ivory bandle, the priest's bands; the smell of the buming blood mixed with that of the incense, which Tryphon bad taken from a small basket and thrown on the altar. Ariagne, a flutist, tuned a simple melody.

'Bring the sceptres, will you?', the priest bissed in the ear of Theodoros, the temple's servant; bis annoyance was difficult to conceal. But Theodoros was busy observing bow the well-formed breast of the flutist was moving under ber peplos in harmony with the movement of her arms. Theodoros' wide tunic could barely bide the effect this elegant movement bad upon bim - an agitation that was not primarily of a religious nature. The priest's admonition reminded bim of bis duties. While be rusbed to a small chamber by the temple, the priest gave the sign to an elderly woman to approach the altar. Trypbon gave ber a silver jug, which be bad filled with the blood of the sacrificial animal.

Even without bis priestly crown one could easily recognize the fifty-years old, tall. man with the well-groomed gray beard as the priest. He was wearing a golden ring decorated with a red stone; the purple stripes of his tunic had picked up the bloodstains of countless sacrifices. And bis long hair, which reached bis shoulders, would impress anyone. Carefully constructed wickerwork of bair locks covered the top of bis baldhead.

Tryphon took the twelve sceptres, which Theodoros bad brought, - simple wooden rods crowned with pines. He erected them one next to the other, placing their sharp bottom into the twelve boles dug behind the altar. Each time be erected a scepter, be raised bis hands with the palms turned towards the setting sun and called with loud voice the name of a divinity. 'Great is Motber Philis!', 'Great is Zeus of the Twin Oakes!', 'Great is Mes Tiamou!', 'Great is Mother Hipta!', 'Great is Apollo of Axiotta!', 'Great is the Tarsian Mother!', 'Great is Artemis Anaitis!', 'Great is Zeus Orkamanites!', 'Great is Mother Leto!', 'Great is the Sun, Apollo Labanas!'. Like an echo the assembled worshippers repeated the acclamations. The screaming of the frightened birds, which bad built their nests in the sanctuary's grove mingled with the symphony of the hoarse voices of the men, the timid whispers of the children, and the shrill voices of the women. 'Great are the gods who rule over Koresa!', the priest completed the invocations.

Everybody's eyes were now fixed on the old lady, who was standing on the uppermost step of the altar. Tatias was a middle-aged woman, but ber face and body still revealed the radiant beauty of ber lost youth. Her gray bair was plaited bebind ber bead, beld by an old fashioned fillet - unlike the fashionable bair-dress of the imperial ladies, which was so often imitated by the wives of the provincial magnates. Tatias stood in front of the burning altar, ber body unbent, straight like the cypresses that surrounded the precinct.

She then approached the altar paying attention not to stain ber white garment with blood. Using the silver goblet in which the priest bad collected the blood of the sacrificial animal she poured the blood on the altar. The whispers of several women among the assembled worshippers did not remain unnoticed. With a proud look, full of contempt for them, she raised ber bands and recited aloud the dreadful words of the curse, reading them from a wooden tablet. "Great gods and you, allobserving Sun, the twelve sceptres I erect against all those who accuse me of poisoning my own son-in-law, Jucundus, for with this accusation they are doing me wrong." "Look at ber," a woman in the crowd whispered, "bow she can read; bow can she claim she knows nothing of poisons and witchcraft?" 
Tatias continued ber cursing with louder and angrier voice. "I curse them all. If their accusations are wrong, let them and all their descendants perisb in the worst manner; let their children become orphans, let their bouse be widowed; neitber on sea nor on land shall they be able to travel; neither their women nor their animals shall give birtb according to nature; the anger of the twelve scepters sball fall on them, on their family, on their livestock, on their property. But should their accusations be just, then let this curse fall upon me. Exactly as this blood is being poured, my own blood shall flow. For this affair and against this slander I bave set up the twelve scepters."

As she uttered the last words she tried to discover in the crowd ber neighbour Syntyche, who was spreading these rumours. After she bad finisbed reciting the text of the curse Tatias descended from the altar and entered the temple followed by the priest. She beld in ber bands the pittakion, a small white-painted wooden tablet, on which she bad written with red paint the text of the curse. In the shrine, she deposited the pittakion on the marble table in front of Mes' statue. On the following morning the attendant would fix the tablet with bronze nails on a lange wooden panel in front of the temple, for everyone to see.

These lines are pure fiction, inspired by an inscription from Kula in Lydia (AD 156/157). "This narrative is based on a fundamental aspect of the performance of rituals that neither ancient descriptions of rituals nor modern studies usually treat: the participants in rituals, either as performers or as audience, are human beings, not free of emotions and experiences, human beings such as the lascivious temple servant, the arrogant priest, or the victim of gossip.

\section{The memory of a ritual: Herodes Atticus, Polydeukion, Nemesis, and the reader}

Herodes Atticus is remembered as the most successful orator of the early second century $\mathrm{AD}$, as the wealthiest man in Athens, great benefactor and constructor of buildings; for the epigrapher, Herodes Atticus is also remem-

${ }^{11}$ G. PETzL, Die Beichtinscbriften Westkleinasiens, Bonn, 1994 (EA, 22), p. 89-90, n 69: “... Since Jucundus was struck by insanity and it was rumoured by everybody that he had been given a potion by his mother-in-law Tatias, Tatias set up a scepter and deposited imprecations in the temple, as defending herself against an imputation, although she was conscious (of her guilt). For this reason the gods exercised a punishment, which she did not escape. Similarly, her son Sokrates, when he was passing by the entrance which leads to the grove, having a sickle in his hands, with which one cuts down vines, the sickle fell on his foot and, thus, he died within a day (or: on the same day) suffering his punishment. The gods at Azitta are great! They demanded that the sceptre and the imprecations made in the temple be annulated; Sokrateia, Moschas, Jucundus, and Menekrates, the children of Jucundus and Moschion and grandchildren of Tatias, annulated this, atoning in every way to the gods. Having reported the power of the gods on a stele, we praise the gods from now on." Recent commentaries: H.S. VERSNEL, "Writing Mortals and Reading Gods. Appeal to the Gods as a Strategy in Social Control", in D. CoHEN (ed.), Law, Society, and Social Control, Munich, 2002, p. 64-65; A. CHANIOTIS, "Under the Watchful Eyes of the Gods: Aspects of Divine Justice in Hellenistic and Roman Asia Minor", in S. ColviN (ed.), Tbe GrecoRoman East. Politics, Culture, Society, Cambridge, 2004 (Yale Classical Studies, 31), p. 11-13; id., l.c. (n. 9), p. 245-246. My novel The Last Confession was presented as a lecture course in Heidelberg (winter term 2001/02). 
bered for the many inscriptions he set up in Attica. ${ }^{12}$ One of these texts was found in the sanctuary of Nemesis in Rhamnous; it is inscribed on the base of one of the many statues that Herodes Atticus erected to honour his deceased foster child Polydeukion (c. 148-150 AD). ${ }^{13}$ Herodes explains the choice of this particular sanctuary for his dedication:

To the goddess Nemesis, to whom he used to sacrifice together with him

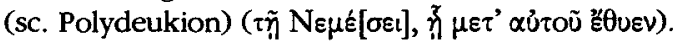

The erection of a statue is the outcome of a chain of considerations, the choice of one among many alternatives concerning the place, the form of representation, and the commemorative text. The choice of this particular place was connected with the memory of Polydeukion; Herodes did not remember only the person of Polydeukion, but also a ritual activity that he used to perform in this particular place ( $\varepsilon_{14}^{\prime} \theta \cup \varepsilon v$, not $\left.\varepsilon^{\prime} \theta \cup \sigma \varepsilon v\right)$ with this particular person.

This short text with its affectionate language ("he loved him like his own son", "the well-disposed", "the one who will be remembered for ever") implies various forms of communication: between Herodes, as a dedicator, and the goddess Nemesis; between Herodes and his deceased friend; between Herodes and the Athenian council and assembly who approved of the dedication; and between Herodes and the future reader of this text. We may be certain that the sacrifices of Herodes and Polydeukion were accompanied by prayers. The prayers expressed expectations, which, here, remain unmentioned. Not the ritual of sacrifice, but the requests, hopes, and expectations of the performers constitute the nucleus of Herodes' memory. We can only speculate about their content. Nemesis is the goddess of punishment, retribution, and justice. Had Herodes and Polydeukion jointly sacrificed in order to achieve justice - or to put it in plain terms, to take revenge upon an enemy? J. Tobin has convincingly argued that the numerous curse inscriptions set up by the sophist in Attica may be his response to threats made against Herodes and his foster children. ${ }^{15}$ Conceivably, Herodes' and Polydeukion's visits, prayers, and sacrifices in the sanctuary of the goddess of retribution are to be seen in the context of conflict. The commemoration of the rituals in the sanctuary of Nemesis presupposes emotions

${ }^{12}$ J. TOBIN, Herodes Attikos and the City of Athens. Patronage and Conflict under the Antonines, Amsterdam, 1997, p. 113-160.

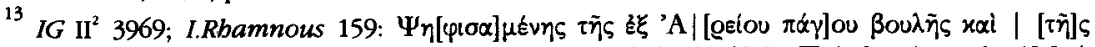

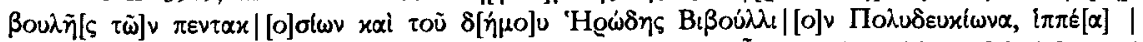

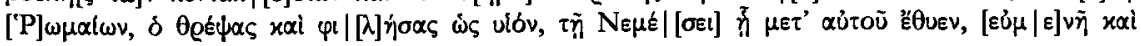

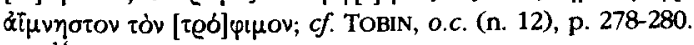

14 The memory of joint activities is also mentioned in other inscriptions set up by Herodes; see $I G \mathrm{II}^{2} 3970+13190 ; 13194 ; 13201$.

${ }^{15} \mathrm{~J}$. TOBIN, "The Curse Inscriptions of Herodes Attikos", in XI Congresso Internazionale di Epigrafia Greca e Latina, Roma, 18-24 settembre 1997. Preatti, Rome, 1999, p. 535-542; cf. ead., o.c. (n. 12), p. 113-160. 
which Herodes and Polydeukion had felt, emotions which are alluded to, but remain unrevealed: anger, hope, fear, vindictiveness.

Evidence for the fact that the performance of a ritual was remembered abounds. In particular, numerous honorary decrees for cult personnel and benefactors stress the fact that the celebrations (sacrifices, processions, ritual meals, etc.) they had prepared excelled in luxury and size, in the aesthetic pleasure they gave to the participants, or in the impression they left upon visitors. $^{16}$ In some cases they praise the fact that a neglected and forgotten ritual was reintroduced. ${ }^{17}$ Herodes' dedication differs from such texts, since it provides evidence for the remembrance of emotionally loaded rituals - it finds closer parallels in the literary sources. Among the numerous allusions to interpersonal tensions during the performance of a ritual in Hellenistic and later literary sources, I only mention the (perhaps best known) example of Theocritus' Second Idy $l l^{18}$ During the performance of a ritual, a magical ritual aiming at bringing back her lost lover (Daphnis), Simaitha recalls another ritual, the procession in honor of Artemis, during which she for the first time encountered Daphnis (lines 64-86, transl. A.S.F. Gow, modified):

Now that I am alone, from what points shall I lament my love? Whence shall I begin? Who brought this curse upon me? Eubulos' daughter, our Anaxo, went as basket-bearer to the grove of Artemis, and in honour of the goddess many wild beasts were brought to the procession that day about her, and among them a lioness ... And Theumaridas' Thracian nurse, now dead and gone, that dwelt at my door, had begged and besought me to come and see the procession. And I, unhappy wretch, went with her, wearing a fair long linen dress, and Clearista's fine wrap over it ... And when I was come already midway on the road, where Lykon's

16 E.g., MAMA VIII, 492 B (honorary decree for the priestess Tata, Aphrodisias, late se-

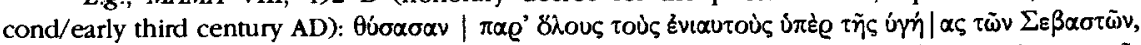

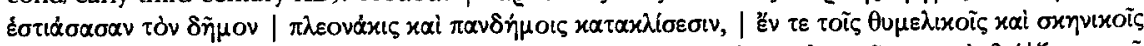

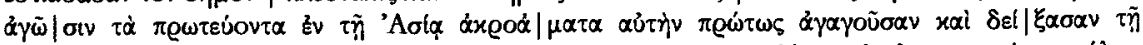

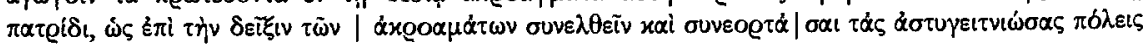
("who offered sacrifices all the years for the health of the emperors, who offered many times banquets to the people, seating the entire people at tables, who brought for the first time for the thymelic and scenical competitions the best plays in Asia and presented them to the fatherland, so that for the presentation of the plays the neighbouring cities came and participated in the festival"). Cf. $I G$ II $^{2} 1315 ; 1329 ;$ SEG 35, 744, lines 17-39.

${ }^{17}$ E.g., IG $\mathrm{II}^{2} 1338$ (Athens, after $86 \mathrm{BC}$ ): Philemon, the epimeletes of the association of Dionysiac artists, was honored for reestablishing the sacrifices in Eleusis, which had been interrupted because of the Mithridatic War and the destruction of the association's altar (lines 10-

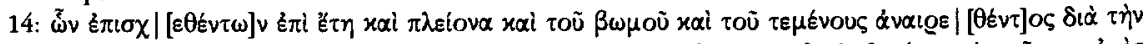

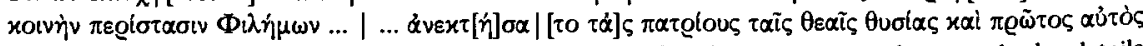
$\theta 00 \alpha \varsigma$...). The decree, which was passed several years after this event, records not only the details of the celebration (duration, sacrifices, libations, banquet, singing of hymns), but also the

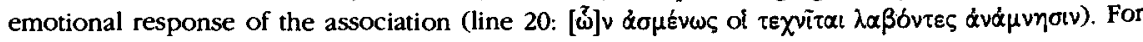
examples from the Imperial period see the article by $S$. Hotz in this volume.

${ }^{18}$ I have very much profited from the discussion of this text by I. PETROVIĆ, Der Artemiskult in der bellenistiscben Dicbtung, Leiden, 2006 (forthcoming, with further bibliography); see also A. DUNCAN, "Spellbinding Performance: Poet as Witch in Theocritus' Second Idyll and Apollonius' Argonautica", Helios 28 (2001), p. 43-56. 
is, I saw Delphis and Eudamippos walking together. More golden than helichryse were their beards, and their chests brighter far than thou, O Moon, for they had lately left the manly labour of the gymnasium. ... I saw, and madness seized me, and my hapless heart was aflame. My looks faded away. No eyes had I thereafter for the procession, nor know how I came home again, but some parching fever shook me, and ten days and ten nights I lay upon my bed.

Here, the emotions of Simaitha frame the magical ritual she performes, and vice versa, her ambiguous emotions are framed by two rituals, the memory of the procession and the curse ceremony she performs. We also observe that Simaitha's attention is distracted from the procession precisely because of her emotions.

\section{Memories of funerals: touching the dead, demonstrating affiliation}

Hardly any other ritual is as emotionally loaded as the burial of the dead. It is, therefore, not surprising if references to the remembrance of the funerary rituals for a particular person abound in the textual evidence. ${ }^{19}$ Here, I should like to discuss a rather neglected aspect of emotionality during burials: the memory of the fact that a mourner touched the corpse in order to express in a direct, intense, and physical way his close relation to the deceased. ${ }^{20}$

Because of the expected emotionality, but also in view of a tendency to theatrical excesses, Greek funerary rituals were often the object of normative regulations. $^{21}$ The relevant documents inform us how a funeral was to be performed. But if we want to find our how a funeral was performed, then we have to turn to the funerary epigrams which often tell us which aspect had been stressed during the particular performance of the ritual. What these texts are interested in is not the general norms, but the individual performance.

19 The detailed descriptions of burials in the literary sources, naturally, concern the burial of important persons, e.g., Dionysios I of Syracuse (Philistos, FGrHist, 556 F 40 b = Plutarch, Pelopidas, 34), Timoleon (Plut., Timol., 39), Hephaistion (Diodorus Siculus, XVI, 115, 4), Demetrios Poliorketes (Plut., Demetr., 53) and Philopoimen (see the article by P. Kató in this volume). For the memory of a worthy funeral see also, e.g., Isaios, 2, 2 (On the estate of Menekles).

${ }^{20}$ A. Chaniotis, "Familiensache: Demonstration von Zusammengehörigkeit im altgriechischen Grabritual", in R. ReichMaN (ed.), 'Der Odem des Menscben ist eine Leuchte des Herm'. Aaron Agus zum Gedenken, Heidelberg, 2006, p. 205-209. Cf. the significance of the $\sigma \tau \varepsilon \varrho v o ̀$ qi $\lambda \eta \mu \alpha$, kissing the deceased, in modern Greece: L.M. DANFORTH, The Death Rituals of Runal Greece, Princeton, 1982, p. 19 and 85 (kissing the skull upon exhumation), p. 40 sq., 73 with pl. 8 (kissing the deceased on the forehead).

21 J. ENGELS, Funenum sepulcrorumque magnificentia. Begnäbnis- und Grabluxusgesetze in der griechisch-nömischen Welt, Stuttgart, 1998; F. FRISONE, Leggi e regolamenti funerari nel mondo greco. 1 Le fonti epigrafiche, Galatina, 2000; E. STAVRIANOPOulou, "Die "gefahrvolle" Bestattung von Gambreion", in C. AMBOS et al. (eds), Die Welt der Rituale ton der Antike bis beute, Darmstadt, 2005, p. 24-37; A. KavoulaKI, "Crossing Communal Space: The Classical Ekphora,

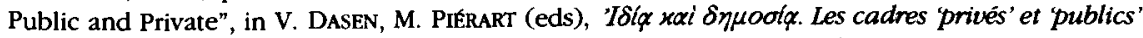
de la religion grecque antique, Liège, 2005 (Kermos, suppl. 15), p. 129-145. 
The authors of many epigrams (and non-metrical epitaphs) underline the personal involvement of close relatives or friends in the funerary ceremony, e.g., through the offering of a crown to the deceased person, ${ }^{22}$ or by assembling the bones and the ashes, or by constructing the grave monument. ${ }^{23}$ The epigrams of the Imperial period that explicitly remind us that the deceased person had been buried by the hands of a close relative or friend are less common. By implying a physical contact between the dead and the mourner they demonstrate an intimate relation and the belonging to the close circle of the family.

A first example of the remembrance of the physical contact between mourner and deceased is the funerary epigram of a woman at Ioulioupolis (Imperial period). Apphe, the deceased woman, addresses the passer-by: "Catulla, the mother who gave birth to me, has also embalmed me." ${ }^{24}$ The offering of the last service through personal involvement of the mourner's own hands is expressed in the grave epigram for a soldier at Tieion (Imperial period): "After a man, who bears the same name as I do, had prepared me as if I were still alive and had let me go into Hades, he honored - -." The rest of the epigram is not preserved, except for the beginning of the word adelpb[--] ("brother"). The relationship of the dead soldier to the man who buried him is not known, but the offering of this last service made the mourner into the deceased person's brother.

We find an explicit reference to physical contact and the use of one's own hands in the epigram for Deidas in Miletoupolis $\left(1^{\mathrm{st}}\right.$ century AD): ${ }^{26}$ "I, the fortunate old man Deidas, who has lived in piety, I am being buried by my alumnus Salbanas, with his own hands (en palamais) in accordance with the pious custom. ${ }^{27}$ The dead man declares his contentedness over having been buried by the hands of his own alumnus and no other. The undying voice which the stone gives to the dead evokes not simply the orderly performance of the ritual, but also the employment of Salbanas' hands, i.e., the last physi-

${ }^{22}$ E.g., TAM V.1, 13 and 156.

${ }^{23}$ E.g., SGO I 01/12/17: "Your father has made this grave with his own hands and with toil"; I 02/03/01: "The father and the brothers and the gray-haired mother assembled the bones and the ash in the bosom (of an urn)"; IV 17/16/01: "Zosimos ... has built the grave with his own hands"; IV 18/01/23: "The son buried the bones of the sweet parents"; IV 22/37/01: "Diomedes has assembled the remains of those who have died long time ago, his uncle and his aunt who had raised him, bringing them from here and there and burying them near the ancestors, under the arch of this ultimate house"; $c f$. I 01/01/07: "I had wished to receive the earth from your hand."

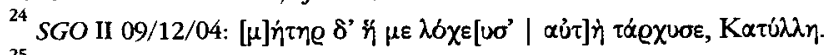

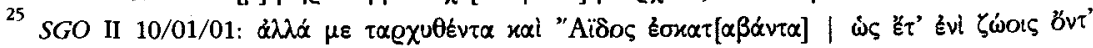

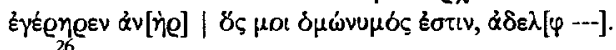

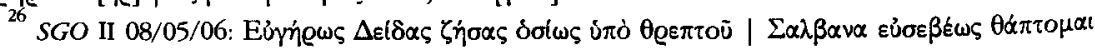
Év $\pi \alpha \lambda \alpha \dot{\mu} \mu \alpha$ เs.

${ }^{27}$ Less explicit in SGO II 09/12/06 (Ioulioupolis): "The children and grandchildren have buried him in his grave, as he had wished." 
cal contact between the deceased and a beloved person. ${ }^{28}$ Another epigram, this time from Nikaia ( $3^{\text {rd }}$ century $A D$ ), reads: "I, the noble Secundus, live here, buried by my father's hands (chersi kedeutheis)." According to the epigram for Kriton of Smyrna ( $3^{\text {rd }}$ century BC) "his children's hands have buried him according to the custom. ${ }^{30}$ Halmyrion in Pompeioupolis (Imperial period) announces from his grave: ${ }^{31}$ "I have been buried by the hands of my beloved children." On a sarcophagus at Aphrodisias ( $4^{\text {th }}$ century AD) we read: ${ }^{32}$ "(He lies) away from the foes, buried by the hands of his friends."

Grave inscriptions very often testify to the fact that a person has been laid to rest under the care of family members, using in a very general manner the verbs ${ }^{\prime} \theta \alpha \psi \varepsilon v /{ }^{\prime} \theta \alpha \psi \alpha \nu$ et $\operatorname{sim}^{33}$ But the texts quoted above differ from this general practice through the conscious reference to the employment of a relative's or friend's hands, hence to the physical contact. The aforementioned references to the last physical contact are not very numerous and they are always formulated in different ways; therefore, they do not belong to the epigrammatic commonplaces.

To underline this particular element of the funerary ritual represents the individual choice of the poets (or their clients). This is significant for four reasons: First, it alludes to the respect for a tradition neglected by others; second, this is the final physical contact between the two persons; third, this contact demonstrates the close relation between the mourner and the deceased person, the fact that they belong to the same family, in a legal or symbolical sense; and fourth, the overcoming of the fear of pollution through physical contact with the corpse attributes to these dead an extraordinary status. I should briefly comment on those four aspects.

First, in two of the epigrams it is either explicitly stated or implied that the performance of the burial by the hands of family members corresponds to the traditional custom (themis). ${ }^{34}$ This explicit reference to the fact that a family respected a tradition implies that others did not. The epigrams which stress the fact that it was the family that personally performed the burial may well be a criticism against the employment of professionals in the treatment of the dead.

Second, the physical contact with the deceased person is the last possibility for the living to manifest close emotional bonds by touching the dead before he departs for the kingdom of the shades, retaining a visual presence

${ }^{28}$ On the memoralisation of rituals through epitaphs see J.W. DAY, "Rituals in Stone: Early Greek Grave Epigrams and Monuments", JHS 109 (1989), p. 16-28.

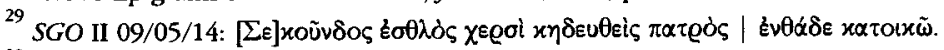

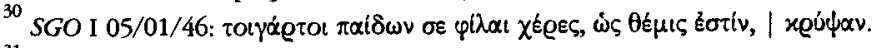

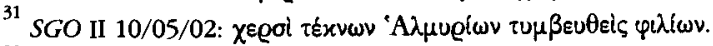

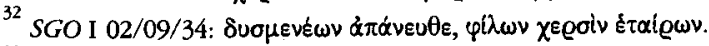

${ }^{33}$ E.g., SGO IV 17/03/03; 20/03/06; 21/01/92.

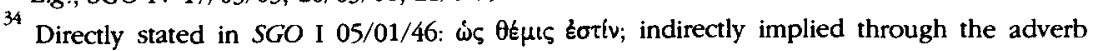

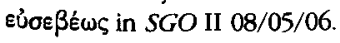


only through memories, images, and dreams. This feeling, which is visualised in the dexiosis scenes of grave reliefs, is also expressed in the epigram for the jurist Konon from Kolybrassos, who died in Thebes in Egypt $\left(3^{\text {di }} / 4^{\text {th }}\right.$ century AD). ${ }^{35}$ His father travelled to Egypt in order to bring the corpse back home: "there came the father from far away and caressed me with his hand, as he saw me lying dead in a foreign place."

The third aspect is, I think, more significant. Physical contact with a dead body causes defilement, and this belief in a miasma, a ritual impurity originating from the corpse, remained alive until Late Antiquity ${ }^{36}$ Normative interventions time and again aimed at defining and limiting the circle of mourners - of women in particular - and, consequently, of those who had polluted themselves through contact with the dead (see note 21). Often only the closest relatives were allowed to attend the funeral. ${ }^{37}$ The physical contact with the dead does not only mean the overcoming of the fear of pollution, because of the extraordinary status of the dead (see infra), it also manifests the sense of belonging to the closest circle of the family - and this is what the aforementioned texts unequivocally stress. A characteristic example for this old concept, that burial is the personal duty of the next of kin, can be found in the epitaph of Eusebie and Philippos. Both died in different places away from home and they were buried separately. Their remains were brought home by their nephew Diomedes (Namara, $2^{\text {nd }} / 3^{\text {rd }}$ century AD): "Diomedes has assembled the remains of those who have died long time ago, his uncle and his aunt who had raised him, bringing them from here and there and burying them near the ancestors, under the arch of this ultimate house." What the epigram places in the foreground is not that Diomedes was any relative of the deceased couple, but the fact that the aunt and the uncle had raised him and had treated him as if he were their own child. The personal service offered by Diomedes is demonstratively assimilated to the service offered by a son to his parents.

Finally, the fourth aspect deserves particular attention. If the fear of pollution was overcome in these cases, it was not only because of the affectionate relation between the mourner and the deceased, but also because the touching of the deceased person indicated his extraordinary status. In general, the touching of objects of reverence is occasionally mentioned in the context of the performance of rituals. The sacred regulation of a cult association in Philadelpheia, e.g., obliged the members to assert ritual purity by taking an

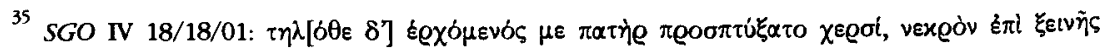

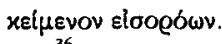

${ }^{36}$ On the early concept of pollution see R. PARKER, Miasma. Pollution and Purification in Early Greek Religion, Oxford, 1983, p. 32-73; on the persistence of this idea see A. Chaniotis, "Reinheit des Körpers - Reinheit der Seele in den griechischen Kultgesetzen", in J. AssmanN, T. SUNDERMEIER (eds), Scbuld, Geuissen und Person, Gütersloh, 1997, p. 142-179.

${ }^{37}$ ENGELS, o.c. (n. 21), p. 49-119, especially p. $50 \mathrm{sq}$. and 99.

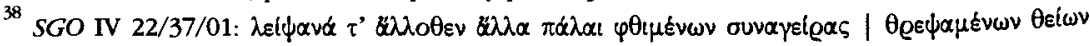

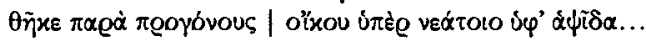


oath; ${ }^{39}$ during the oath ceremony, the mystai of the association touched with their hand the stone inscription with the sacred regulation. Directly connected with the funerary practices and our context is a report of Plutarch on the annual celebration of the battle of Plataia: ${ }^{40}$

On the sixteenth of the month Maimakterion, which corresponds to the Boiotian month Alalkomenios, they held a procession, which is led forth, at break of day, by a trumpeter who sounds the signal for battle; wagons filled with myrtle and wreaths follow, then a black bull, then free-borne youths who carry libations of wine and milk in jars and pitchers of oil and myrrh; for no slave is permitted to assist in this service, since the men had died for freedom; and at the end comes the chief magistrate of the Plataians, who may not at other times touch iron or dress himself with any other garment than white, but on this occasion wears a purple tunic, carries a water-jar from the city's archive, and marches, sword in hand, through the city to the graves. Then he takes water from the spring, washes with his own hands the stelae and anoints them with myrrh; then he slaughters the bull at the pyre and praying to Zeus and Hermes Chthonios he invites the brave men who died for Greece to come to the banquet and the offerings of blood. Then he mixes a mixer of wine and makes a libation saying: 'I drink to the men who died for the freedom of the Greeks'. The Plataians observe these rites down to this very day.

The behaviour on this particular day is characterised by a series of reversals of normality, which are often observed especially when the dead are believed to come to this world (e.g. during the Anthesteria): ${ }^{41}$ the archon wears a purple tunic and carries a sword, breaking taboos connected with his office; ${ }^{42}$ the slaves are not serving; the stelae are not washed by women or servants, but by the archon. Again, if Plutarch explicitly points out the fact that the archon washed the graves of the war dead "with his own hands" where it would have sufficed to write that he "washed" the stelae -, this cannot be a coincidence. It underlines the extraordinary status of these dead, this day, this service.

These observations allow us to fully understand the significance of a small group of texts that refer to burials with the participation of the entire community. These sources have recently been the object of a penetrating

${ }^{39}$ LSAM 20; recent discussions (with further bibliography): S.C. BARTON, G.H.R. HORSLEY, "A Hellenistic Cult Group and the New Testament Church", JAC 24 (1981), p. 7-41; CHANIOTIS, l.c. (n. 36), p. 159-162.

${ }^{40}$ Plut., Arist., 21, 3.

41 L. DEUBNER, Attische Feste, Berlin, 19662', p. 93-123; W. BURKERT, Homo necans. Interpretationen altgriechischer Opferriten und Mythen, Berlin, 1972, p. 236-273; J. BREMMER, The Early Greek Concept of the Soul, Princeton, 1983, p. 108-122; A. BIER,, "Karion, die Karer und der Plutos des Aristophanes als Inszenierung eines anthesterienartigen Ausnahmefestes", in A. BIERL, P. voN MÖLLENDORFF (eds), Oncbestra. Drama, Mythos, Bübne. Festscbrift für Hellmut Flasbar anlässlich seines 65. Geburtstages, Stuttgart/Leipzig, 1994, p. 30-43.

42 A. CHANıOTIS, "Gedenktage der Griechen: Ihre Bedeutung für das Geschichtsbewußtsein griechischer Poleis", in J. Assmann (ed.), Das Fest und das Heilige. Religiöse Kontrapunkte zur Alltagswelt, Gütersloh, 1991, p. 131-133. 
analysis by Christopher Jones: ${ }^{43}$ they report that a private funerary ceremony, organised and performed by a family, was interrupted by a demonstration of the masses and was transformed into a public ritual with the participation of the entire community. In one case this seems to have occurred against the family's wish. ${ }^{44}$ In all these cases, the physical contact with the corpse played an important part. The sources repeatedly report that the assembled masses seized and carried away ( $\dot{\alpha} \varrho \pi \dot{\alpha} \zeta \varepsilon v$ ) the corpse. As I shall argue, this demonstrative seizure of the body from the circle of the family aimed at stressing the extraordinary status of this person (heroisation) and at presenting the entire community as family of the deceased.

The earliest testimony concerns the burial of an anonymous woman in Knidos (late $1^{\text {st }}$ or early $2^{\text {nd }}$ century AD). ${ }^{45}$ She was a descendant of the benefactor Theopompos, who had achieved for his fatherland liberty and exemption from taxes. As the woman's death became known, "the people were shocked beyond measure because of her virtue and her reputation." A decree, which was passed, while the funerary ceremony was still in progress gives us a direct impression of the emotions: The people "assembled with great zeal in the theatre [lacuna], while her corpse was being carried out." In many Greek cities the theatre served as the place where the popular assembly met, but also as the place where the people spontaneously assembled on important occasions. ${ }^{46}$ We may suspect that the funeral procession passed near the theatre. "And after the people had seized her body, they unanimously demanded that they may bury her with the participation of the entire people, and manifested through acclamations her virtue, in order that she receive also after her death the appropriate honours."

The second testimony dates to the early $2^{\text {nd }}$ century $\mathrm{AD}$ and concerns the funeral of Tatia Attalis in Aphrodisias: ${ }^{47}$ The relevant decree first praises the

${ }^{43}$ C.P. JONEs, "Interrupted Funerals", PAPbA 143 (1999), p. 588-600.

44 P. HerrmanN, "Zwei Inschriften von Kaunos und Baba Dag”, OpA 10 (1971), p. 36-39:

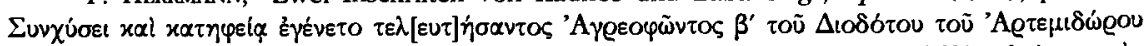

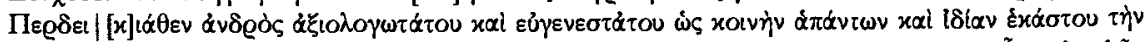

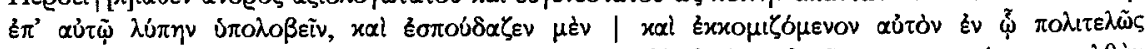

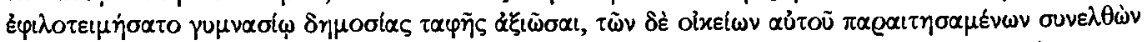

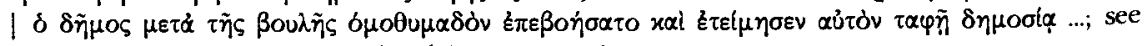
JONES, l.c. (n. 43), p. 589 sq., 594-596 (SEG 50, 1109).

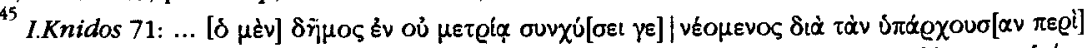

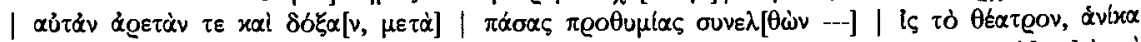

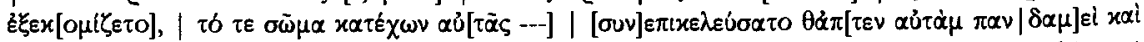

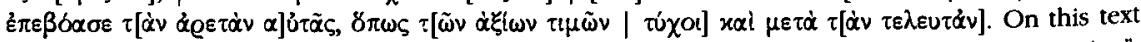
see A. Bielman, R. Frei-Stolba, "Femmes et funérailles publiques dans l'antiquité gréco-romaine", in Études de Lettres. Revue de la Faculté des Lettres, Univ. de Lausanne, Lausanne, 1998, p. 5-33.

46 A. Chaniotis, "Theatricality Beyond the Theater: Staging Public Life in the Hellenistic World", in B. LE GUEN (ed.), De la scène aux gradins. Thêatre et représentations dramatiques après Alexandre le Grand dans les cités bellénistiques. Actes du Colloque, Toulouse 1997, Toulouse, 1997 (Pallas, 41), p. 224 sq.

${ }^{47}$ J. REYNOLDS, C. RouECHÉ, "The Funeral of Tatia Attalis at Aphrodisias", Ktema 17 (1992)

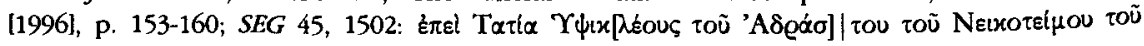


woman for her achievements and then states in the unfortunately very fragmentary concluding section: "Since she has now reached the end of her life, sooner than the destined time (promoiros), for this reason the city has publicly [lacuna], and everybody unanimously seized her corpse [lacuna]." Here, too, the people interrupted the family funeral and carried the corpse away in order to bury it in a public ceremony.

The third testimony (not discussed by C.P. Jones) is provided by Philostratus in his narrative of the funeral for Herodes Atticus in Athens. ${ }^{48}$ The burial which was being performed by his freedmen - his familia in the legal sense in Marathon was interrupted by the Athenian ephebes, who marched from Athens to Marathon, "seized the body with their own hands" ( $\chi$ egoiv $\dot{\alpha} \varrho \pi \alpha \dot{\alpha} \alpha \nu \tau \varepsilon \varsigma)$, brought it back to Athens in procession, and buried it there, near the stadium which Herodes had donated. Philostratus reports that all the Athenians attended the funeral lamenting the death of their benefactor "like

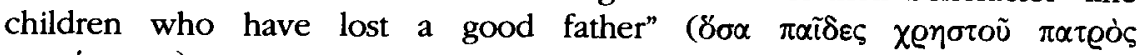

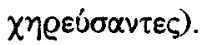

Christopher Jones has plausibly suggested that these public demonstrations did not simply express the grief about the loss of a benefactor, but also presented a conscious attempt to animate the elite for larger benefactions. There can be little doubt that Jones' assumption is correct. These demonstrations fulfilled the same function as other forms of honouring benefactors (honorary decrees, honorary statues, acclamations, crowns, etc.). By demonstrating the people's gratitude they encouraged other members of the elite to follow the benefactor's model, and thus they were one of the strategies of persuasion in the communication between the elite and other social groups. But we should not overlook two essential features of these spontaneous reactions, which are either explicitly stated or at least alluded to in these testimonia. The first aspect is the extraordinary status, i.e., the heroisation of these persons; this is manifest in the fact that their burial took place within the city wall. Agreophon of Kaunos was buried in the gymnasium (note 44), Tatia Attalis in her grandfather's monument in the city, Herodes Atticus in the stadium (note 48).

The second aspect is that the immediate aim of these actions was to transform a family ritual into a public ritual. The participation of the entire

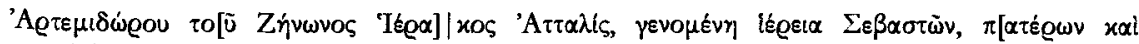

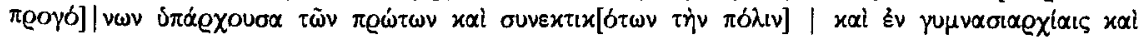

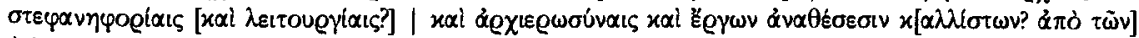

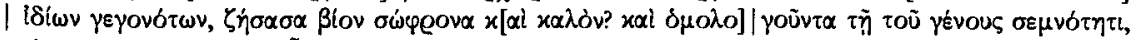

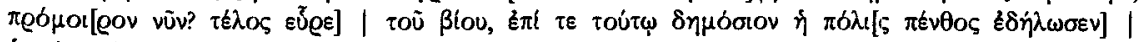
$\dot{\alpha} \varrho \pi \dot{\alpha} \sigma \alpha \sigma \alpha \dot{\alpha} \tau \varepsilon \tau \dot{\partial} \pi \tau \tilde{\omega} \mu \alpha \delta \dot{\delta} \mu \theta u \mu \alpha \delta \delta \dot{v}[---]$.

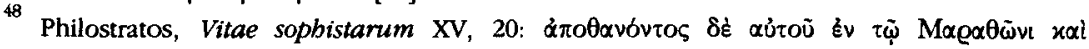

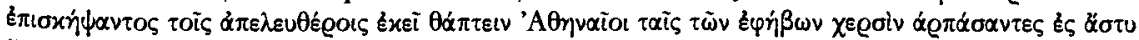
ไ่̧

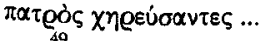

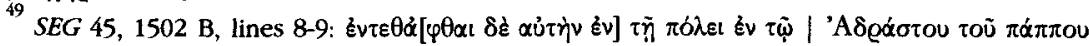

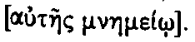


community in the funeral, in other words the incorporation of the community into a family ritual, created the fiction of the orphaned people. This is directly stated by Philostratus. This fiction of an intimate, indeed of a family relation between the people and the elite was in fact often manifested, precisely in this historical period, through the honorary titles of "the son of the people", "the daughter of the people" etc., but also through consolatory decrees for deceased benefactors. ${ }^{30}$ This established a relationship of mutual care. In these cases a ritual was interrupted, in order to be intentionally transformed into a ritual of togetherness.

Striking in these narratives is the remembrance of the ritual as shared experience, as an event that united the people in a joint, emotionally intense reaction - one notices the use of the words denoting unanimity in these testimonia,$-^{51}$ but also as an event which overcame the social boundaries which separated the family of the deceased from the rest of the community, the elite from the people. The fact that these decrees concerning the participation of the entire people in the funeral were inscribed guaranteed that these rituals were not forgotten. The inscription preserved the memory of the unique event that had bound the entire community into a virtual family.

The explicit mention of physical contact in the aforementioned texts cannot be coincidental. As already mentioned, neither the relevant epigrams nor the testimonia about the interruption of the funeral are numerous, and they consequently originate in the conscious effort to demonstrate a close association and affiliation with a deceased person.

\section{Rituals as an intentionally shared experience}

The evidence, which has hitherto been discussed, concerns the memory of emotional, interpersonal contact during the performance of rituals. It shows that the Greeks were conscious of the emotional power and the lasting impression of this experience. Was this effect intended?

A very attentive observer of human behaviour, the Hellenistic poet Theocritus, treats in his 15 th Idyll precisely this subject. The setting of the poem is the popular festival of Adonis, celebrated in Alexandria. In Theocritus' poem, Gorgo, who has heard that the queen has prepared something impressive for the festival, invites a friend of hers to join her in a visit to the palace, in order to "watch" (tbasomenai) Adonis. ${ }^{52}$ These women attended the

50 J.H.M. STRUBBE, "Bürger, Nichtbürger und Polis-Ideologie", in K. DEMOEN (ed.), The Greek City from Antiquity to the Present. Historical Reality, Ideological Construction, Literary Representation, Louvain-Paris-Sterling, 2001, p. 36-38.

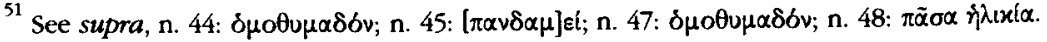

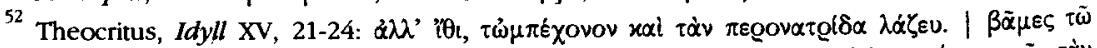

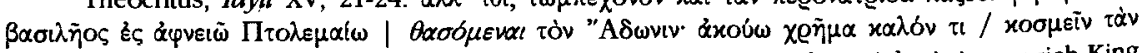
$\beta \alpha \sigma$ ì Ptolemy's palace. I'm told the Queen is giving a fine show"; transl. A.S.F. Gow). $C f$. H. vON HESBERG, "Temporäre Bilder oder die Grenze der Kunst. Zur Legitimation frühhellenistischer Königsherrschaft im Fest", JdI 104 (1989), p. 62 sq.; id., "Privatheit und Öffentlichkeit der früh- 
festival not just as participants but as the audience of a staged spectacle about which they will be able to talk later (line 25): "what you've seen you can talk about, when you've seen it and another hasn't". Then Theocritus' poem develops into an ekphrasis, the description of the things admired by the two friends. What is interesting in our context is both the wish of Gorgo to be accompanied by a friend and share with her the joy of the participation and the interaction between the two women, their dialogue while they admire the paraphernalia of the festival, the colourful clothes of the god, and the beauty of his image. 53

The visit to a sanctuary is a ritual for which the worshippers need to fulfil certain purity regulations. Although the primary aim is the ritualised communication with a divinity, this can be combined with an aesthetic experience, which, again, is often shared experience. Herodas presents in his fourth mime the visit of two women in the sanctuary of Asklepios in Cos as a primarily aesthetic experience consisting of the observation of the works of art, which had been dedicated there. Similarly, Theocritus' second mime combines the ritual element of the attendance of a ritual (here a procession) with the aesthetic experience of thea, which a friend is invited to share (lines 66-72):

Eubulus' daughter, our Anaxo, went as basket-bearer to the grove of Artemis, and in honour of the goddess many wild beasts were brought to the procession that day about her, and among them a lioness ... And Theumaridas' Thracian nurse, now dead and gone, that dwelt at my door, had begged and besought me to come and see the procession.

Both Theocritus and Herodas based their poems on the observation that one should best perform and watch rituals not alone, but in the company of persons to whom one has an emotional link. This idea is also expressed, albeit in a paradoxical way, in the anecdote about the misanthrope Timon. One of the best-known rituals in ancient Athens was the drinking competition at the Anthesteria, the so-called Choes. ${ }^{54}$ This evening was traditionally regarded as an opportunity to invite friends. The host provided the crowns and aromatic substances, but unlike the usual practice of a Greek symposium, on this particular occasion the guests had to bring their own food and wine. Another violation of the rituals of the symposium was that slaves were allowed to attend and that the guests drank in silence. The Choes can,

hellenistischen Hofarchitektur", in W. HOEPFNER, G. BRANDS (eds.), Basileia. Die Paläste der bellenistischen Könige. Internationales Symposion in Berlin, 16.12. - 20.12.1992, Mainz, 1996, p. 93 sq.; CHANIOTIS, l.c. (n. 46), p. 247. On the Adonis festival in Alexandria see most recently G. WEBER, Dichtung und höfische Gesellschaft. Die Rezeption von Zeitgeschichte am Hof der ersten drei Ptolemäer, Stuttgart, 1993, p. 170 sq., 284. See also M. LAMBERT, "Gender and Religion in Theocritus' Idyll 15: Prattling Tourists at the Adonia”, Acta Classica 44 (2001), p. 87-103.

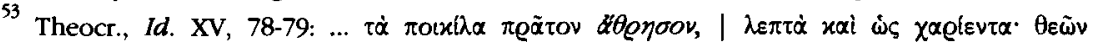

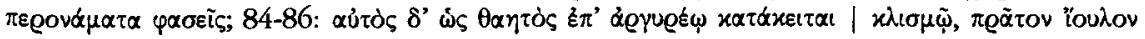

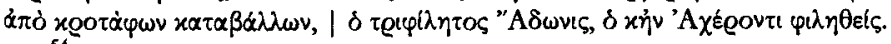

${ }^{54}$ On the Anthesteria and the rituals of the Choes see the bibliography supra (n. 41) and N. ROBERTSON, "Athens' Festival of the New Wine", HSCP 95 (1993), p. 197-250. 
therefore, be understood as a reversal of the traditional norms. It is said that even Timon the Misanthrope once celebrated this festival with his only friend. The reversal in the case of the misanthrope was the very fact that he tolerated this elementary company. After the two men had drunk their wine in silence, the other man said to Timon: "What a nice party we are having!" "Yes", was the misanthrope's answer, "if only you weren't here." placed himself outside the norms of human company could not tolerate the presence of another man, not even during a ritual of reversal. What does the story tell us? Only a misanthrope can wish for what the other Greeks felt was an annoying violation of the norms of the symposion. The silence, the isolation, the lack of prayers, libations, and toasts for well being, friendship, love, and success, all this corresponded to the normality of the misanthrope. For the normal Greek, ritual and celebration mean togetherness.

These literary testimonia reflect in my opinion how much the Greeks valued the feeling of togetherness in the performance of rituals, as an experience that needed to be shared with others. This is also indirectly reflected by the fact that the darkest of rituals, cursing, had to be performed in isolation. ${ }^{56}$ We have seen that whereas the joint performance of a ritual, be it a libation and a sacrifice $(\$ 3)$, be it the attendance of a festival or the visit of a sanctuary (Theocritus, Herodas), be it the ritual of the symposium (Choes), was remembered, the lack of togetherness could be-missed or critisized. In the light of this evidence we may understand the cultural context of a particular aspect of Greek religious vocabulary, namely the countless composita with the preposition syn, which express the fact that a ritual was not simply celebrated, but celebrated with others. Naturally, such composita abound in the vocabulary of cult associations, the purpose of which was according to Aristotle the joint performance of sacrifices and social intercourse, ${ }^{57}$ e.g., with regard both to the designation of the associations

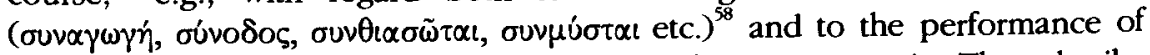
rituals. The worshippers of Sarapis in a cult association in Thessalonike designated themselves as "those who jointly revere the bed of the great god

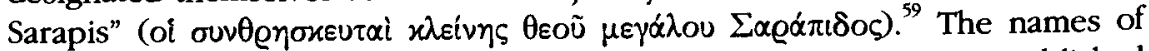
other associations stressed the joint pilgrimage to sanctuaries. An unpublished Hellenistic inscription from the sanctuary of Hermes Kedrites in Simi Viannou

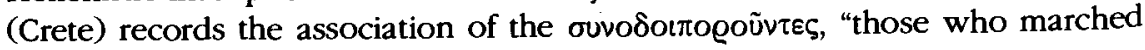

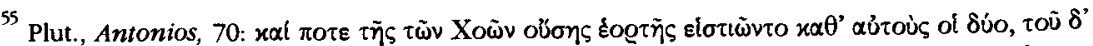

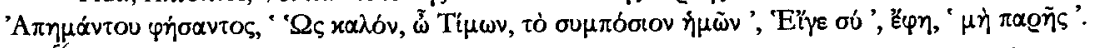

${ }^{6}$ F. GRAF, Gottesnäbe und Schadenzauber. Die Magie in der griechiscb-römischen Antike, Munich, 1996, p. 188-192.

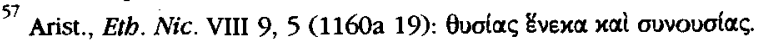

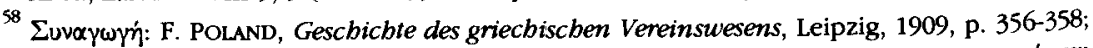

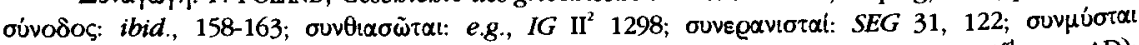
(members of an association of mysts): POLAND, o.c., p. 39; e.g., SEG 36, 1114 (Mysia, $3^{\text {td }}$ cent. AD);

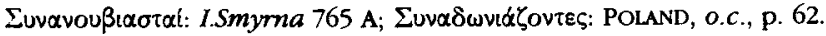

${ }^{59}$ IG X.2.1, 192 (c. AD 250). 
together" to the barely accessible sanctuary on the Sacred Mountain (Hieron Oros), ${ }^{60}$ and a contemporary inscription in Antimacheia in Cos was set up by the association of "those who walk together" to the sanctuary of Zeus Hyetios

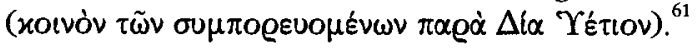

Theoretically, any word designating a ritual action can build a composite word with syn, but some of these composita seem to particularly stress the joined performance or attendance of rituals. This is, e.g., the case with the usage of $\sigma u v \theta u \omega$, $\sigma u v \theta u \sigma i \alpha$, and $\sigma u v \theta u i n s$ (joint offering of a sacrifice), ${ }^{62}$

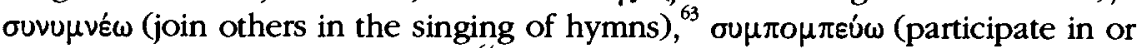
lead a procession with others), ${ }^{64}$ and $\sigma u v \varepsilon u \sigma \varepsilon \beta \varepsilon{ }^{\prime} \omega$ (piously honour the god together with others). ${ }^{65}$ The great significance of joined worship is also

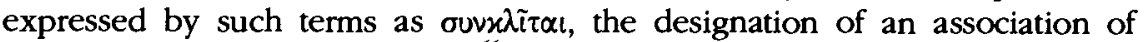
worshipers of Theos Hypsistos, ${ }^{66}$ ouvunvos, the designation of those who

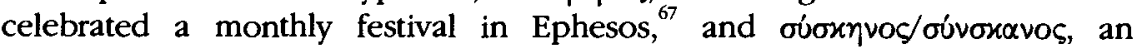
originally military term designating the soldiers who shared the same tent, but also used in connection with worshippers. ${ }^{68}$

The healing miracles of Asklepios recorded in an inscription on the Insula Tiberina in Rome are a nice example of the value attributed to the shared experience of rituals. ${ }^{69}$ After his rescue, the worshipper was expected to come to the sanctuary and express his gratitude to the god in public (line 9: $x \alpha i$

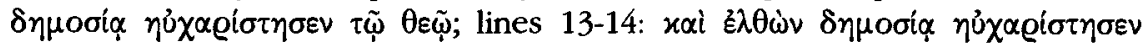

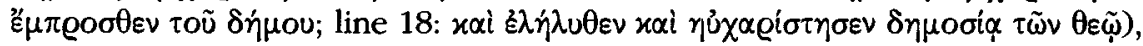

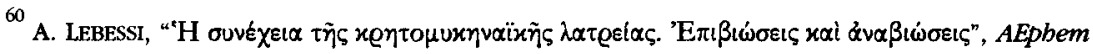
(1981), p. 4.

${ }^{61}$ Syll..$^{3} 1107$ ( $3^{\text {rd }}$ century BC); POLAND, o.c. (n. 58), p. 165.

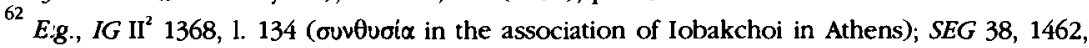
lines $69,82-87$ (joint offering of sacrifices by magistrates and villages at the Demostheneia of Oinoanda); $S E G 43,718$ (donation of old aromatic wine during a sacrifice on the occasion of the

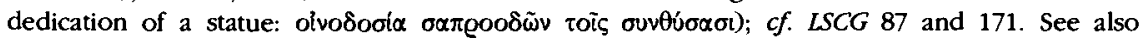
POLAND, o.c. (n. 58), p. 34, 255-256; C.P. JONES, "Joint Sacrifice" at lasus and Side", JHS 118 (1998),

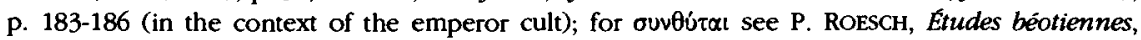
Paris, 1982, p. 113 with examples from Boiotia; cf. I.N. ARNAOUTOGLOU, Thusias beneka kai sunousias. Private Religious Associations in Hellenistic Athens, Athens, 2003, p. 45 with n. 41.

${ }^{63} S E G$ 37, 961 (delegation of boys and girls sent by Laodikeia to Klaros, early 2nd cent. AD).

${ }^{64}$ SEG 38,1462, 1. 58 (the agonothetes leads the procession of the Demostheneia together with other magistrates; Oinoanda, 2nd cent. AD); 1.84 (participation in a procession); SEG 43, 703-704; POLAND, o.c. (n. 58), p. 267, note ***.

65 I.Stratonikeia 115 (joined worship of locals and foreigners during a festival; Panamara,

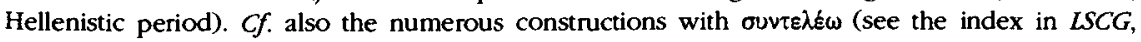
p. 358), which, however, place the sharing of the expenses in the foreground.

${ }^{66}$ IG X.2.1, 70 (Thessalonike, AD 66). This term probably refers to the celebration of ritual banquets and symposia. This assumption is supported by a still unpublished dedication to Theos

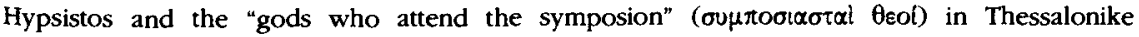
(Imperial period); for a preliminary report see SEG 47, 963.

\footnotetext{
${ }^{67}$ SEG 39, 1202.

${ }^{68}$ POLAND, o.c. (n. 58), p. 129.

${ }^{69}$ Syll. ${ }^{3} 1173=$ IGUR I 148.
} 
presumably through acclamations, praise, and thanksgiving dedications. The other worshippers in the sanctuary are presented as sharing the emotions of

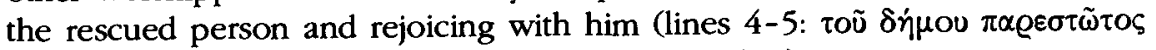

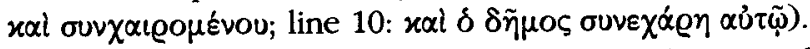

I conclude the selection of evidence for how much the Greeks esteemed the performance of a ritual as a transpersonal emotional experience which brought a community together with the funerary epigram for a magistrate (prytanis) in Kyzikos (late $2^{\text {nd }}$ century BC) ${ }^{70}$ The epigram refers to Theodotos' mother who is mourning her son, "the prytanis who greatly rejoiced together with his fellow citizens during the libations." Here, it is not the performance of the ritual that is in the foreground, but the pleasure Theodotos felt while experiencing this ritual together with his fellow citizens.

\section{Control of emotional interaction during the performance of rituals}

The evidence, which has hitherto been discussed, concerns the memory of emotional, interpersonal contact during the performance of rituals; it shows that the Greeks were conscious of the emotional power and the lasting impression of this experience. Did this affect the norms, which regulated the performance of rituals?

This may well be the case in the considerations behind normative interventions concerning burials. ${ }^{71}$ The paper of Manolis Skountakis in this volume shows that the demonstration of emotions during the performance of funerary rituals could indeed be the object of close observation and criticism, the control of emotions a reason for praise. The intense emotionality observed during the performance of funerary rites is explained by the role of interpersonal relations: the demonstration of emotions was addressed to the dead and usually watched by an audience. But what about the effect of interpersonal relations among the participants during the performance of other rituals? Were the Greeks aware of the danger that emotional, sexual, social, and other tensions might disturb the successful performance of a ritual and distract attention from it? Did sacred regulations aim at putting aside potential tensions and increasing the harmony among the participants in order to safeguard the successful performance of a ritual? Can emotionality help us understand the reasoning behind sacred law?

These questions are hard to answer, especially since we often have only cult regulations and not the reasoning behind them. And yet we can identify measures in cult regulations, which are closely related to the anxiety caused by the danger that a ritual might fail because of the tensions among the participants or other distractions.

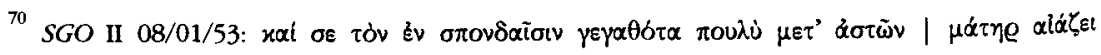

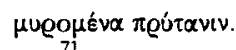

${ }^{71}$ See supra n. 21 and in particular the study by A. Kavoulaki. 
Documents referring to the organization of festivals often demonstrate the effort of civic communities to safeguard the celebration of the festival in an orderly manner. One of the most common measures is the celebration especially of the sacrifice and the banquet in small groups. ${ }^{72}$ We have seen an example already in Antioch on the Pyramos $(\$ 1)$. This is also the case, e.g., in Teos where the decree concerning the celebration of a festival in honour of King Antiochos III stipulates: ${ }^{73}$

Every symmoria (civic subdivision) should set up an altar for King Antiochos the Great and his sister, Queen Laodike, in its own place, next to the symmoria's altar, and should offer a sacrifice on this altar.

But what about the foreign residents of Teos, who did not belong to a symmoria? The decree continues (lines 24-25):

Also the other inhabitants of our city should sacrifice and celebrate in their own dwellings as best they can.

A sacred regulation of Bargylia concerning the festival of Artemis Kindyas (late $2^{\text {nd }} /$ early $1^{\text {st }}$ century BC) made every tribe responsible for raising a beautiful sacrificial animal. A beauty contest among the cows would determine the sequence of the tribes in the procession; the sacrifice and the banquet were to take place separately for each tribe. ${ }^{74}$ Some time later, the Bargylians observed (or were made to observe after protests) that this regulation discriminated against the foreign residents. A new decree gave also the metics the permission to raise their own cow and attend the sacrifice.

When a wealthy citizen of Aphrodisias, Attalos Adrastos, provided the funds for a sacrificial installation and banqueting halls near the temple of Aphrodite, he made sure that the citizens were to celebrate divided into tribes: ${ }^{75}$

(I, Adrastos,) have promised to construct with my own money a sacrificial installation with banquet facilities and the buildings around it for the manifest,

72

2 Chaniotis, l.c. (n. 10), p. 155 with n. 65.

${ }^{73}$ SEG 41, 1003 II, lines 9-17.

${ }^{74}$ For these cult regulations̀ see W. BLÜMEL, "Inschriften aus Karien I", EA 25 (1995), p. 35-39; id., "Ein weiteres Fragment des Kultgesetzes aus Bargylia", EA 28 (1997), p. 153-156; K. ZIMMERMANN, "Späthellenistische Kultpraxis in einer karischen Kleinstadt. Eine lex sacra aus Bargylia", Chiron 30 (2000), p. 451-485; W. BLÜMEL, "Ein dritter Teil des Kultgesetzes aus Bargylia", EA 32 (2000), p. 89-94; S. HoTz, "Bigger, Better, More - Die Kleinstadt Bargylia im Bann eines Festes", in AMBOS et al. (ed.), o.c. (n. 21), p. 59-65; SEG 45, 1508 A/B; SEG 48, 1328; SEG 50, 1101.

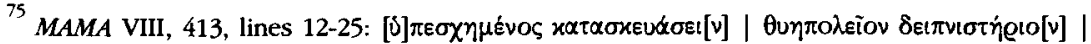

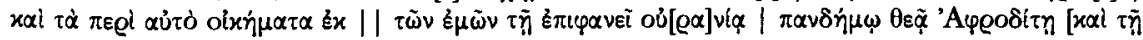

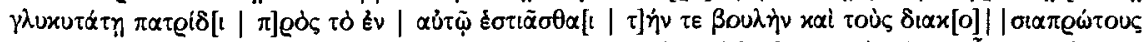

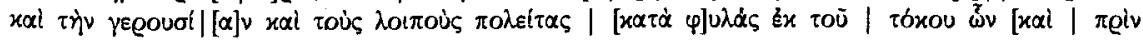

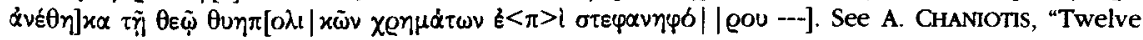
Buildings in Search of a Location. Known and Unknown Buildings in Inscriptions of Aphrodisias", in C. RATTE (ed.), Aphrodisias Papers $I V$ (forthcoming). 
heavenly goddess Aphrodite, the one who embraces the entire citizen-body, and for the fatherland, in order that the council and the 200 first citizens and the gerousia and the rest of the citizens divided according to their tribes receive banquets funded from the interest of the money for sacrifices, which I donated earlier to the goddess, during the stephanephorate of ---.

Practical considerations easily explain such measures: in this way the sacrifice could be funded in a more expedient way through money allocated to or coming from the subdivisions; the competition among civic subdivisions for the biggest and most beautiful sacrificial animal increased the festival's glamour; the sacrificial meat could be distributed among the participants in an orderly way; the intrusion of strangers could be avoided. But beyond these practical reasons, the conception of the community of worshippers as a community of togetherness and conviviality must have been a significant factor.

Many regulations concerning festivals include measures for orderly behaviour that stem from the fear that social and emotional tensions might undermine a celebration. The foundation document of the festival Demostheneia in Oinoanda, e.g., provides for a special police force: "The organiser of the festival should appoint twenty whip-bearers (mastigopboroi) who will go in front, dressed in white garments and without an undergarment, with shields and whips, and will take care of order during the events in the theater according to the instructions given to them by the agonothetes."

One of the most important pieces of evidence for such measures concerns the rituals of a private cult association, the Athenian Iobakchoi, the worshipers of Dionysos. ${ }^{7}$ A private cult association is by definition founded on interpersonal relations, on the accord among individuals, on their interest in conviviality - in a private association everybody knows everybody. An Athenian inscription of AD 178 preserves the protocol of a meeting of the association of the Iobakchoi, during which the statutes were approved (lines 1-31).

To good luck! When Arrios Epaphroditos was Archon, on the 8th day of the month Elaphebolion, the members were called to an assembly for the first time by Claudius Herodes, who has been appointed a priest by Aurelius Nikomachos, after the latter had served as a vice priest for 17 years and as priest for 23 years; he gave his office (to Herodes) still in his lifetime, for order and for the glory of the association of Bakchus. Herodes (i.e., the new priest) has appointed Nikomachos (i.e. the retiring priest) vice priest. Nikomachos read out the statutes that had been introduced by the former priests Chrysippos and Dionysios. After the priest and the first Bakchos (i.e., one of the club's officers) had given their consent, the members exclaimed:

We want to have these statutes forever! - The priest has done a fine job! -

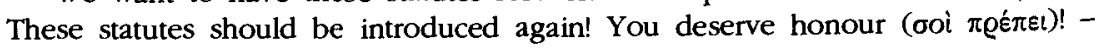

${ }^{76}$ M. WORRLE, Stadt und Fest im kaiserzeitlichen Kleinasien. Studien zu einer agontstiscben Stiftung aus Oinoanda, Munich, 1988, p. 219-220.

${ }^{7} I G \mathrm{II}^{2}$ 1368; LSCG 51 . 


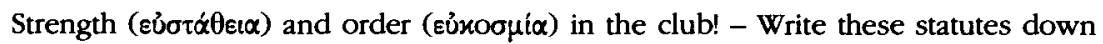
on a stele! - Let us take a vote!

The priest proposed: - Since I, and my fellow priests and all of us are of the same opinion, we will put this to a vote, as you demand.

And the president of the assembly, Rufus, the son of Aphrodisios, put this issue to a vote: - Those who think that the statutes which were read out should be valid and should be written down on a stele may raise their hand.

All the members raised their hand. They called out: - Long lives our priest Herodes! - Now we are happy! Now our Bakchus Club is the first among all (Bakchic) clubs! - The vice priest has done a fine job! - Let the stele be made!

The vice priest said: The stele should be on the column, and the statutes will be engraved. The members of the board will vigorously make sure that nothing is cancelled.

What follows is a text of more than 130 lines with very detailed rules. The importance of harmony in the club is stressed by the procedure of admittance - only worthy and suitable candidates would be accepted upon vote. Regular contribution of wine for the monthly celebrations was the most important requirement. The statutes are also preoccupied with the celebration of convivial gatherings on the ninth day of every month and on the festive days dedicated to Dionysos in peaceful and orderly meetings (lines 63-95):

No one is allowed to sing, to be loud or applaud in the dining room (stibas); the distribution (of wine) should take place in an orderly and quiet manner under the instructions of the priest or the chief Bakchos ... If someone starts a quarrel or does not behave properly or goes to another bed or insults someone or uses defamatory words, the victim of the insult or of the defamation should present as witnesses two members, who can declare under oath that they have heard how this person has been insulted and defamed; and the one who has insulted or defamed shall pay to the club 25 drachmas as a fine. And the one who has started a quarrel should pay the same amount of 25 drachmas; these persons are not allowed to attend the gathering of the Iobakchoi until they have paid the fine. And if someone reaches the point of striking others, the member who has been struck will submit a written accusation to the priest or the vice priest, who is then obliged to call an assembly; and the Iobakchoi should pass a judgement upon vote under the guidance of the priest, and in addition to any other punishment they should determine the period during which the convict will not be allowed to attend the gatherings, and a fine of up to 25 denarii. And the person who has been beaten will be subject to the same punishment, if he publicly accuses him, instead of declaring the incident to the priest or the chief Bakchos. The person responsible for order who neglects to expel those who quarrel will be subject to the same punishment ...

Admittedly, we are dealing with a particular situation. The club's primary aim was not the cult of Dionysus, but drinking together. But the preoccupation with harmony and the fear of conflicts that might undermine the group's cohesion apply mutatis mutandis to all groups of worshippers. It is interesting to note that the fines were not to be paid to the member who had been insulted or beaten, but to the club - the entire club was the victim of such 
actions that evidently had their roots in pre-existing tensions, which received additional input from wine consumption. There can be no doubt that the reform of the statutes of the association followed upon a crisis, although this is only alluded to in the protocol. The acclamation "Strength and order in the club!" presupposes the danger of falling apart and the lack of order. The acclamation "Now we are happy!" presupposes an earlier unhappiness, which has now come to an end. The acclamation "Now our Bakchus Club is the first of all clubs!" is directly related to the competition among the Dionysiac associations. And the remark that the priest Nikomachos gave up his office after 17 years (after 40 years in the leadership of the association) "for good

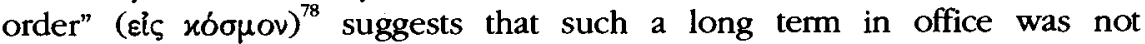
approved by all the members. The problems of the association are revealed by the measures taken to solve them: the uncontrolled recruitment of new members; neglecting the donation of wine; explosions of emotions that lead to quarrels, insults, and even open violence during the regular meetings. We also notice the efforts of the club to keep these tensions unnoticed by others. We can be sure that such problems did not occur only in this Bakchic association. Another association made a dedication on behalf of the concord

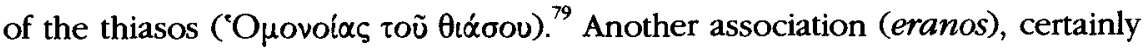
not a Bakchic one this time, but dedicated to friendship and to the commemoration of the dead, was also threatened by quarrel and disorder (lines

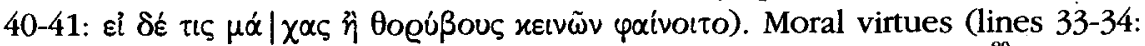

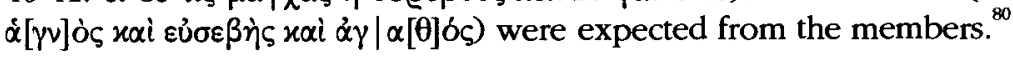

\section{The emotional background of normative texts and ritual dynamics in the Hellenistic and Imperial period}

The emotional background of rituals is one of the factors that explain why rituals are a dynamic phenomenon. Ritual actions cannot remain the same when their performers and spectators change. Even when the norms that determine ritual actions remain unchanged, the ritual as an interpersonal, emotional, shared experience and communication changes simply because of the fact that the experiences and emotions of its performers and their viewers differ. Paraphrasing the statement of a famous philosopher one might say that "one cannot celebrate the same ritual twice."

In Classical studies, the discussion of rituals has primarily been the study of origins, the study of meanings, the study of unchangeable norms. Given the large number of cult regulations from the Hellenistic and Imperial periods

${ }^{78}$ Kóopos can also mean "decoration", but I think that a meaning closer to "order, good behaviour, good rules, honour" best matches this context.

${ }^{79} I G \mathrm{II}^{2} 4985$.

${ }^{80} I G \mathrm{II}^{2}$ 1369. For another example see SEG 31, 122 (decree of an eranos, Athens, c. AD 121), now in E. LuPU, Greek Sacred Law. A Collection of New Documents, Leiden, 2005, p. 177-190 n ${ }^{\circ} 5$ : "If anyone engages in a fight in the association, on the following day the one who started the fight shall pay a fine of five drachmas; the one who joined it (shall pay) five drachmas." See also ARNAOUTOGLOU, o.c. (n. 62), p. 101-102 with n. 43 and p. 156. 
we may study the dynamic of rituals and the changes in norms. One of the tools for understanding the changing norms is to take into consideration the emotional background of rituals. Ritual failure can be caused by many factors: a natural catastrophe, a war, the presence of an impure person, but also the emotional tensions among the participants. The effect of some of these factors can be reduced if measures are taken, and some of the measures taken by cult regulations may in fact be understood - perhaps not exclusively, but at least partially - as efforts to reduce this danger.

Let us take the example of regulations concerning ritual purity. It has been observed that an increasing number of sacred regulations demand not only purity of body, but also purity of mind. ${ }^{81} \mathrm{M}$.W. Dickie has recently argued that the regulations against the presence of morally stained persons in sanctuaries are connected with the anxiety aroused by the imminent arrival of the god. Their background is the feeling that the god might take offence if he knew his sanctuary was desecrated by the presence of unworthy persons. ${ }^{82}$ This hypothesis is plausible, but hard to prove, and I doubt whether it can be the only explanation for the development of the idea of moral impurity. But it is conceivable that the presence of suspected or known culprits would not only disturb the divinity whose epiphany was expected with anxiety, but would also annoy the other worshippers and distract their attention from the ritual. There is in fact a text (not considered by DiCKIE), which explicitly states that the presence of an impure person disturbs the performance of a mystery rite. It is the sacred regulation of a cult association at Philadelpheia (late $2^{\text {nd }} /$ early $1^{\text {st }}$ century BC). ${ }^{83}$

A free woman is to be chaste and shall not know the bed of, nor have sexual intercourse with, another man except her own husband. But if she does have such knowledge, such a woman is not chaste, but defiled and full of endemic pollution, and unworthy to reverence this god whose holy things these are that have been set up. She is not to be present at the sacrifices, not to offend the purifications and cleansings, not to see the mysteries being performed.

An adulteress, whose presence during the mysteries is felt to be the ultimate disturbance, is often in small communities the subject of gossip, and one wonders whether it was her ritual impurity alone or also the indignation she provoked among the other participants that explains this regulation.

${ }^{81}$ A. Chaniotis, l.c. (n. 36), p. 152-173; J.N. BREMmeR, "How Old is the Ideal of Holiness (of Mind) in the Epidaurian Temple Inscription and the Hippocratic Oath?", ZPE 141 (2002), p. 106108 (with the comments in EBGR 2002,15).

${ }^{82}$ M. W. DickIE, "Who were privileged to see the gods?", Eranos 100 (2002), p. 109-127.

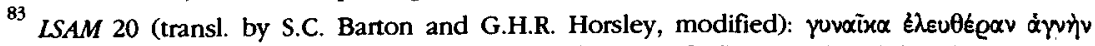

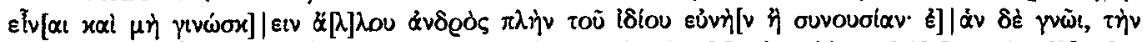

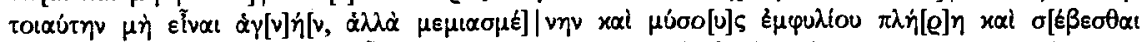

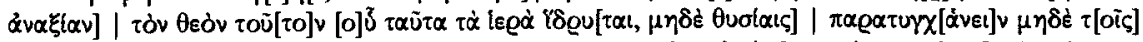

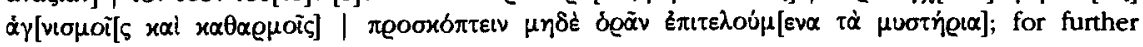
bibliography see supra $\mathrm{n}$. 39 . 
A comparable distraction, the presence of prostitutes, may have been perceived as a potential disturbance of religious processions in Thasos. A long inscription (c. 470-460 BC) concerns the upkeep of streets leading from and to the sanctuaries of Herakles and the Charites. ${ }^{84}$ Already the first editor of the inscription, $H$. DuCHÊNE, suspected that the text might be seen against the background of regulations concerning processions that took place on these streets during one or more festivals. One of the most enigmatic clauses of the text (lines 30-35) contains prohibitions against climbing up on the roof of a particular group of buildings ("public houses") and against women appearing in the windows of these houses. ${ }^{85}$ A.J. Graham has ingeniously suggested that these prohibitions are associated with prostitution. More recently A. Henry has argued that the first prohibition against climbing up on the roof refers to men (pimps or male prostitutes) and the second to female prostitutes exhibiting themselves to customers ("no one shall go up onto the roof of maisons publiques in order to be seen, nor shall any woman show herself from the windows"). According to the same scholar, another clause stipulates that another section of the street should be free from dung and women; no woman should stand in front of a brothel and be exhibited for prostitution

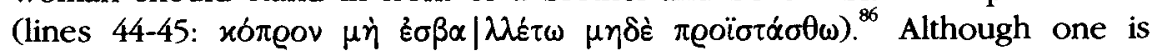
tempted to explain the interest of this regulation in prostitution as an awareness of the distraction it might cause to the solemn performance of processions, this is far from certain.

We are on safe grounds when we examine the long regulation concerning order during the performance of the mysteries of Andania (traditionally dated to $92 \mathrm{BC}){ }^{87}$ Already the oath of the sacred officials (bieroi) obliges them to

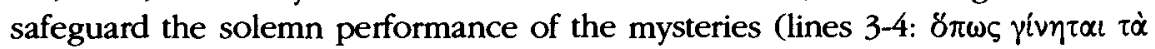
$\varkappa \alpha \tau \dot{\alpha} \tau \dot{\alpha} \nu \tau \varepsilon \lambda \varepsilon \tau \dot{\alpha} \nu \mid \theta \varepsilon o \pi \varrho \varepsilon \pi \tilde{\omega} c)$ and defines the dangers: violations of law and

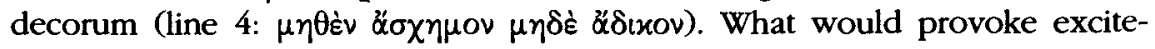

${ }^{84} \mathrm{H}$. DUCHÊNE, La stèle du port. Fouilles du port 1. Recherches sur une nouvelle inscription thasienne, Paris, 1992; SEG 42, 785.

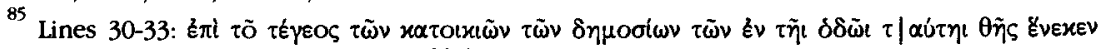

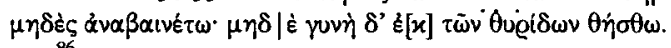

${ }^{86}$ A.J. Graham, “The Woman at the Window: Observations on the 'Stele from the Harbour' of Thasos", JHS 118 (1998), p. 22-440; rejected by F.X. RYAN, "Über die Fenster zur Strasse in Athen und Piräus", Boreas 23/24 (2000/2001), p. 73-75; A. HENRY, "Hookers and Lookers: Prostitution and Soliciting in Late Archaic Thasos", ABSA 97 (2002), p. 217-221.

${ }^{87}$ IG V.1, 1390 = LSCG 65; recent discussions M.L. ZUNINO, Hiera Messeniaka. La storia religiosa della Messenia dall'etá micenea all'età ellenistica, Udine, 1997, p. 301-334; T. FIGUEIRA, "The Evolution of the Messenian Identity", in: S. HoDkInson, A. Powell (eds), Sparta. New Perspectives, London, 1999, p. 211-244; L. Piolot, "Pausanias et les Mystères d'Andanie. Histoire d'une aporie", in J. RENARD (ed.), Le Péloponnèse. Archéologie et Histoire. Actes de la rencontre internationale de Lorient (12-15 mai 1998), Rennes, 1999, p. 195-228; C. CHANDEZON, "Foires et panégyries dans le monde grec classique et hellénistique”, REG 113 (2000), p. 81-85; L. PIOLOT, "Le recrutement des musiciens pour les fêtes à l'époque hellénistique : le cas messénien", in P. BrulE, C. VENDRIES (eds.), Chanter les dieux. Musique et religion dans l'Antiquité grecque et romaine. Actes du colloque des 16,17 et 18 décembre 1999 (Rennes et Lorient), Rennes, 2001, p. 279-306. On the date see now $S E G 52,377$ (AD 24). 
ment and disturb the mysteries becomes clear when one reads the clothing regulations conceming women: expensive garments with extravagant decoration (lines 15-26), in particular see-through clothes (line 16: $\mu \eta$

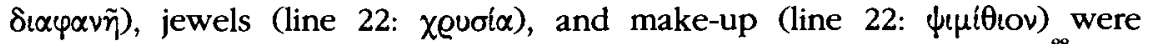
prohibited. These clauses are a combination of old religious taboos ${ }^{88}$ and pragmatic considerations about factors that might distract attention from the solemnity of the rites. The presence of valuables might attract thieves ( $c f$. lines 75-78), and the value of objects (bed- and silverware) kept in the tents was consequently limited to 300 drachmas (line 38). Those who misbehaved during the performance of the sacrifices and the mysteries ${ }^{89}$ by paying no attention to the orders, by not using pious language and violating the rule of ritual silence (euphemia), ${ }^{90}$ or by not behaving according to decorum, were to be flagellated and removed from the sacred place (lines 39-45).

It is equally tempting to consider the measures taken in order to limit the circle of the participants in rituals, by excluding, e.g., stained persons, foreigners, and other outsiders, as aiming at increasing the unity of the worshippers and banning potential excitements and conflicts: stained persons are often parties to a conflict; ${ }^{91}$ foreigners distract the attention, do not know how to behave, and often ask silly questions as an anecdote makes clear: ${ }^{92}$

The Boiotians sacrifice to the gods those eels of the Kopaic Lake which are of surpassing size, putting wreaths on them, saying prayers over them, and casting barley-corns on them as on any other sacrificial victim; and to the foreigner who was utterly puzzled at the strangeness of this custom and asked the reason, the Boiotian declared that he knew one answer, and he would reply that one should observe ancestral customs, and it was not his business to justify them to other men.

The Boiotian was of course right. Such archaic rituals continued to be practiced without any justification - they did not have a meaning, but they had a function. ${ }^{93}$ But new regulations had to be explained and justified in the

88 E.g., knots which are associated with binding and magic are not allowed (lines 22-23).

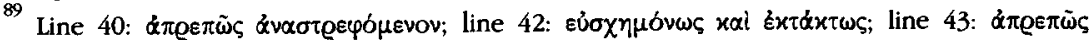

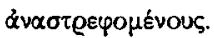

${ }^{90}$ On the notion of euphemia see GöDDE, l.c. (n. 6), p. 24-46, especially p. 27-30.

${ }^{91}$ For such prohibitions in connection with the asylia see A. CHANIOTIS, "Conflicting Authorities: Greek Asylia between Secular and Divine Law in the Classical and Hellenistic Poleis", Kernos 9 (1996), p. 65-86.

92 See, e.g., Agatharchides, FGrHist, 86 F 5 (apud Athenaios, VII, 297d-e, transl. by G.B. GuLICK, modified). For the exclusion of foreigners in Greek cult see P. BUTZ, "The Double Publication of a Sacred Prohibition on Delos: ID 68, A and B”, BCH 118 (1994), p. 69-98, who explains ethnic exclusivity in cult as connected with ethnic identity; cf. ead., "Prohibitionary

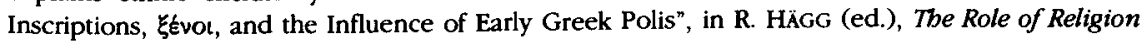
in the Early Greek. Polis, Stockholm, 1996, 75-79; For regulations concerning entry in sanctuaries in general, see most recently LuPU, o.c. (n. 80), p. 14-21 (for foreigners see p. 19-20).

93 A. Chanions, "Ritual Dynamics in the Eastern Mediterranean: Case Studies in Ancient Greece and Asia Minor", in W.V. HARRIS (ed.), Rethinking the Mediterranean, Oxford, 2005, p. 143-146. 
assembly. ${ }^{94}$ They reflect negative experience in connection with the performance of rituals. It is for them, for the new cult regulations, that scholarship should consider more than in the past the possibility that an awareness of the emotional background of rituals was a factor just as important as the respect towards traditions.

Seminar für Alte Geschichte und Epigraphik

Angelos Chaniotis

Marstallhof 4

D - 69117 HEIDELBERG

Email: angelos.chaniotis@unz.uni-beidelberg.de

${ }^{94}$ A. CHANIOTIS, “Negotiating Religion in the Cities of the Eastern Roman Empire", Kernos 16 (2003), p. 177-190. 